\title{
Nanoparticles of silver oxide immobilized on different templates: highly efficient catalysts for three-component coupling of aldehyde- amine-alkyne
}

\author{
Yuqing Zhou, Tingting He, and Zhiyong Wang* \\ Hefei National Laboratory for Physical Science at Microscale and Department of Chemistry, \\ University of Science and Technology of China, Hefei Anhui, 230026, China \\ E-Mail: zwang3@ustc.edu.cn
}

\begin{abstract}
Silver (I) oxide nanoparticles immobilized on different solid supports were employed in catalyzing an aldehyde-amine-alkyne coupling reaction. It was found that the alumina-supported $\mathrm{Ag}_{2} \mathrm{O}$ was the most active catalyst. The scope of the corresponding reaction substrates was extended by virtue of these new catalysts. The feasibility of recycling of the alumina-supported $\mathrm{Ag}_{2} \mathrm{O}$ catalyst was also examined.
\end{abstract}

Keywords: Nanoparticles, templates, three-component coupling

\section{Introduction}

Propargylamines are synthetically versatile and key intermediates ${ }^{1}$ for preparation of many biologically active nitrogen compounds such as conformationally restricted peptide isosteres, oxotremorine analogues, $\beta$-lactams and polyfunctional amino derivatives. A range of efficient and mild metal-catalyzed reactions based upon the nucleophilic addition of in situ generated metal acetylides to imines and enamines have been reported. ${ }^{2}$ Recently, some silver (I) compounds were also used to catalyze $\mathrm{A}^{3}$-coupling (aldehyde-alkyne-amine) reactions to afford propargylamines smoothly. ${ }^{3}$ On the other hand, the development of nano-metal catalysts ${ }^{4}$ is gaining favor in industry because of their high catalytic activities. Normally, nanoparticles of the catalyst are immobilized on the corresponding templates and therefore they can be separated from the reaction mixture easily, which can allow for the reuse of catalysts and provides for an environmental benign reaction. ${ }^{5}$ Several classes of solids have commonly been used as absorbents in organic chemistry such as alumina, diatomite, silica gels, clays, carbon nanotubes etc. ${ }^{6}$ Furthermore nanoparticles can exhibit special chemical properties. ${ }^{7}$ Methods involving hydroxyapatite-supported copper and layered double hydroxide-supported gold catalyst to construct propargylamine skeleton have been reported respectively. ${ }^{8}$ Herein, we reported that nanoparticles of silver (I) oxide immobilized on different templates catalyze the $\mathrm{A}^{3}$-coupling of 
amines, alkynes and aldehydes and give rise to the propargylamines with excellent yields and rapid reaction rates.

\section{Results and Discussion}

Initially, we designed and selected a range of templates to support silver oxide. They are silica sphere, diatomite, multi-wall carbon nanotubes (MWCNT) and alumina. In this way, we attempted to obtain different sizes of nanoparticles of silver oxide as potential heterogeneous catalysts. TEM images (Figure 1) show the particle diameters of the silica sphere-, diatomite-, MWCNT- and alumina-supported $\mathrm{Ag}_{2} \mathrm{O}$ are mainly in the range of 18-20 nm, 13-16 nm, 10-12 $\mathrm{nm}$ and 6-8 nm, respectively. X-ray photoelectron spectroscopy (XPS) analysis indicated that $2.7 \%, 3.4 \%, 4.3 \%$ and $3.9 \%$ of Ag were found in the silica sphere-, diatomite-, MWCNT- and alumina-supported $\mathrm{Ag}_{2} \mathrm{O}$, respectively. X-Ray powder diffraction (XRD) pattern of these catalysts are consistent with their components of these compounds.

(a)
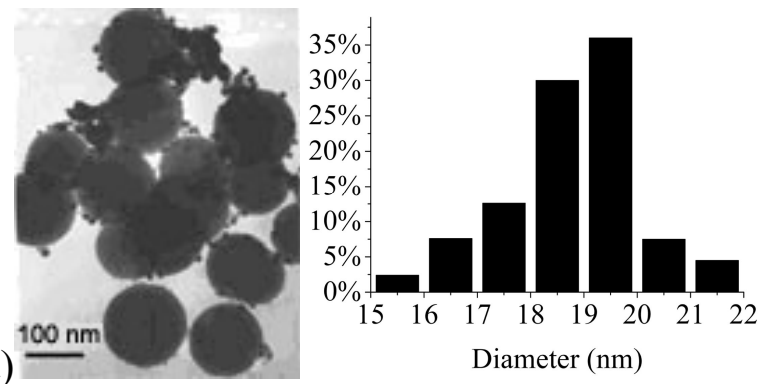

(b)
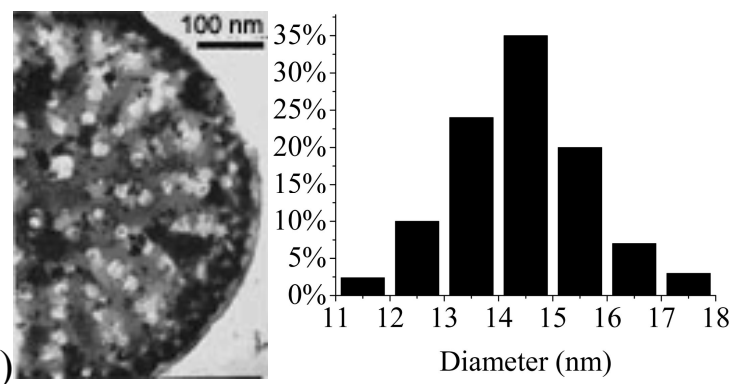

(c)
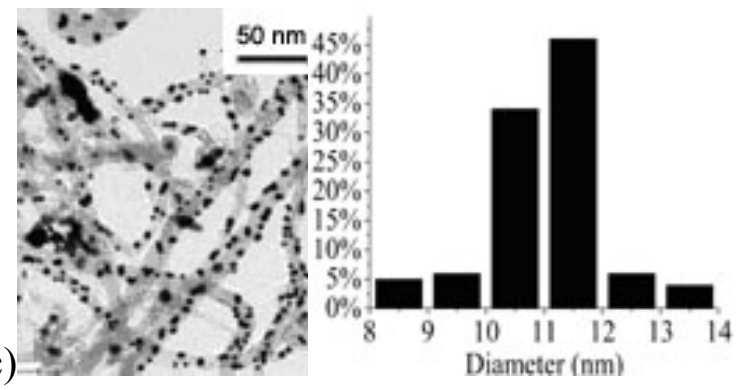

(d)

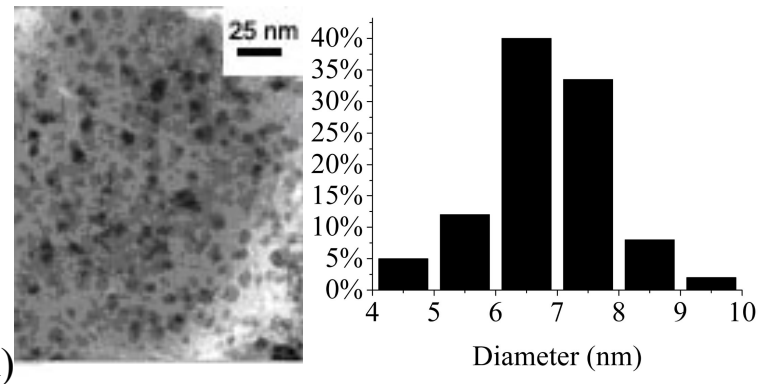

Figure 1. (a) TEM image of $\mathrm{Ag}_{2} \mathrm{O} /$ silica-sphere and the particle dispersion. (b) TEM image of $\mathrm{Ag}_{2} \mathrm{O}$ /diatomite and the particle dispersion. (c) TEM image of $\mathrm{Ag}_{2} \mathrm{O} / \mathrm{MWCNT}$ and the particle dispersion. (d) TEM image of $\mathrm{Ag}_{2} \mathrm{O} /$ alumina and the particle dispersion.

To examine the catalytic activity of the silver oxide catalysts supported by different templates, benzaldehyde ( $2 \mathrm{mmol})$, phenylacetylene $(2.4 \mathrm{mmol})$, diethylamine $(3 \mathrm{mmol})$, water $(2 \mathrm{~mL})$, and the corresponding catalyst $(50 \mathrm{mg})$ were mixed in a $10 \mathrm{~mL}$ of flask. Then the mixture was stirred and the reaction was carried out at $100{ }^{\circ} \mathrm{C}$. The results are shown in Table 1 . It was found that $\mathrm{Ag}_{2} \mathrm{O}$ immobilized on the templates (Table 1, entries 1-4) showed much higher catalytic activity 
than that without any template (Table 1, entry 5). More importantly, alumina- and MWCNTsupported silver oxide were more efficient, giving $92 \%$ and $89 \%$ yield in 2 hours (Table 1 , entries 3-4) whereas the reactions catalyzed by the silver oxide immobilized on diatomite and silica sphere took a longer time to generate the corresponding products with much lower yields (Table 1, entries 1-2). In the case of alumina-supported $\mathrm{Ag}_{2} \mathrm{O}$, only $1.8 \%$ mole of loading catalyst worked well for this coupling reaction. Increasing the catalyst amount did not enhance the yield greatly.

Table 1. $\mathrm{A}^{3}$ coupling reaction catalyzed by $\mathrm{Ag}_{2} \mathrm{O}$ immobilized on different templates

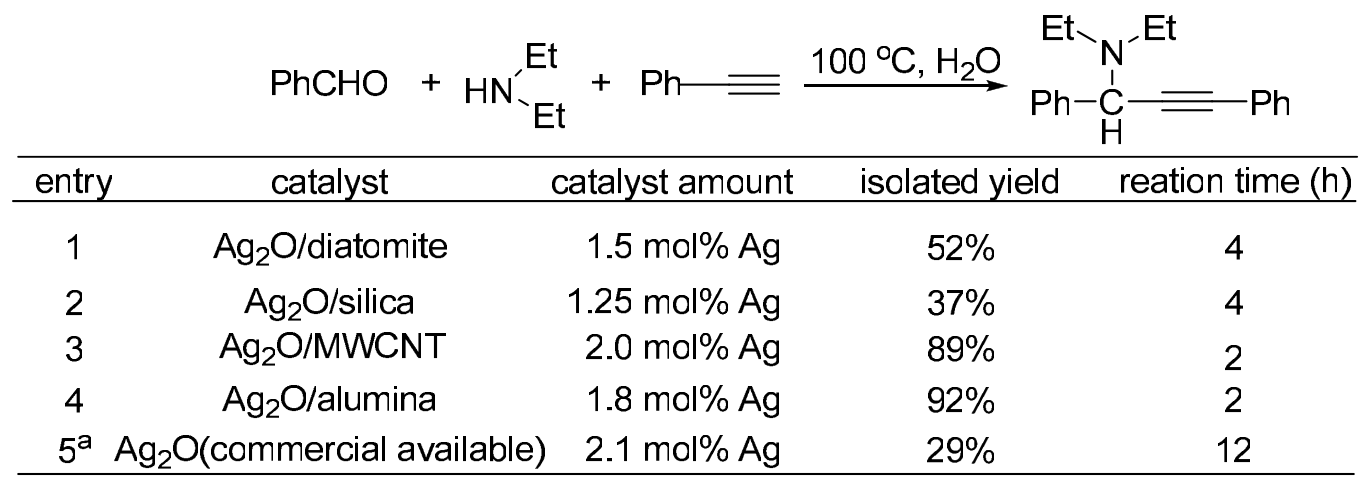

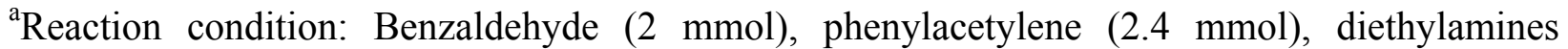
$(3 \mathrm{mmol})$, water $(2 \mathrm{~mL})$ and commercial available $\mathrm{Ag} 2 \mathrm{O}(5 \mathrm{mg})$ at $100{ }^{\circ} \mathrm{C}$.

On the basis of the higher catalytic activity, the silver oxide supported by alumina and MWCNT were selected to catalyze the $\mathrm{A}^{3}$-coupling reaction. A variety of aldehydes and amines bearing different functional groups were employed as the reaction substrates to explore the scope and generality for the catalyst application. All the results are summarized in Table 2. From Table 2 , it was found that various aldehydes such as aromatic, aliphatic and heterocyclic aldehydes could be used as reaction substrates. All of these aldehydes displayed high reactivity under the conditions. Aliphatic aldehydes (Table 2, entries 6-7, 10-15, 17-18) showed a little higher reactivity than aromatic aldehydes (Table 2, entries 1-5, 8-9, 16). As for the aromatic aldehydes, electron-withdrawing groups on the aromatic ring disfavored the reaction (Table 2, entries 2, 8) while electron-donating groups have little influence on the reaction (Table 2, entries 3-5, 16). When dialkylamine, cyclic amine and heterocyclic amine were employed as the reaction substrates, the corresponding reaction also gave the corresponding propargylamines with excellent yields under standard conditions (Table 2, entries 1-18). When a primary amine or an aromatic amine was employed as a substrate, the reaction yield was very low and many side products were observed, perhaps due to the further addition of the generated secondary amine to the aldehyde. As for acetylene substrates, both aromatic alkyne and aliphatic alkyne (Table 2, entries 9-10) displayed high reactivity, giving the corresponding products with excellent yields.

Table 2. $\mathrm{A}^{3}$-coupling reaction catalyzed by $\mathrm{Ag}_{2} \mathrm{O} /$ alumina and $\mathrm{Ag}_{2} \mathrm{O} / \mathrm{MWCNT}$ 


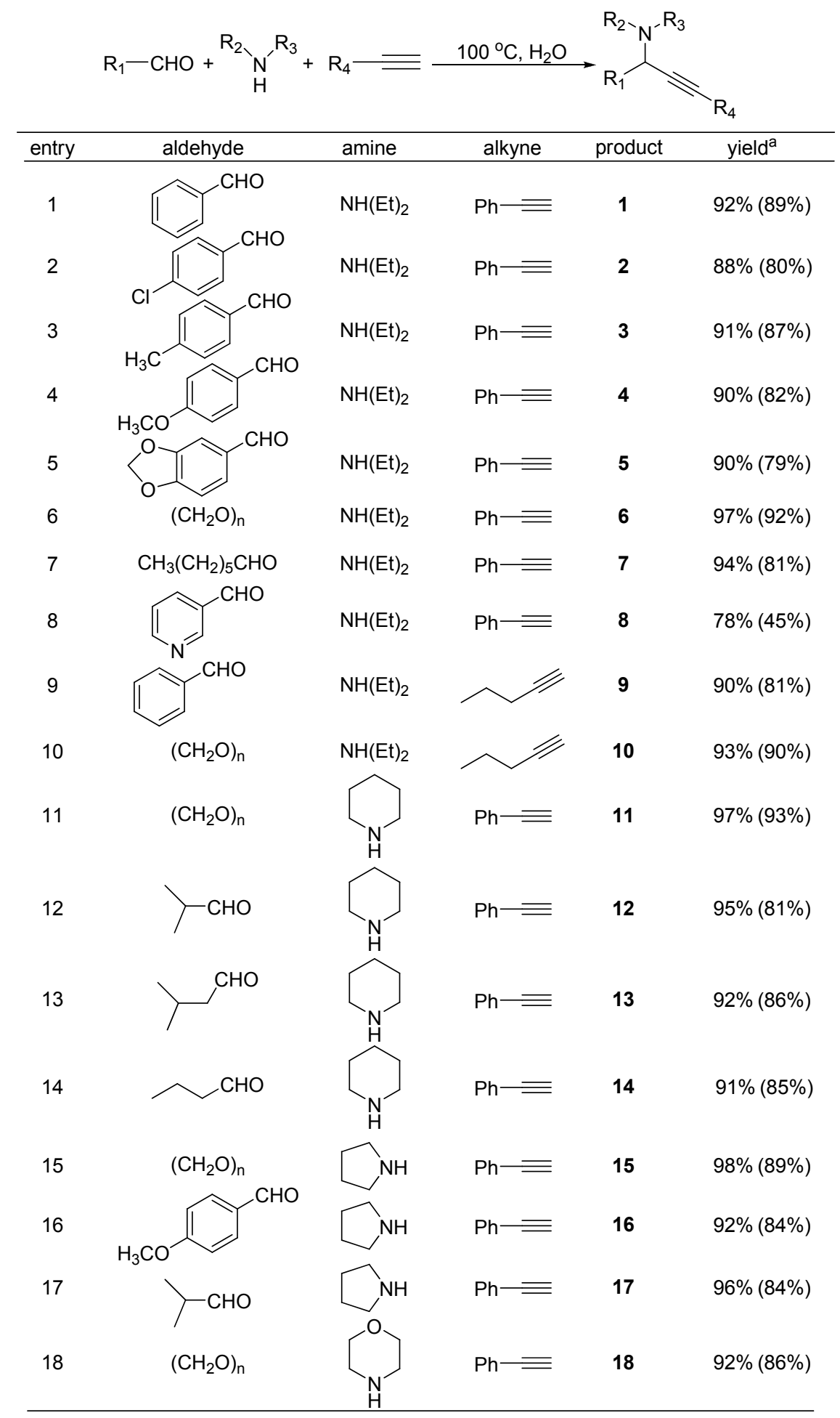

a Isolated yields catalyzed by $\mathrm{Ag} 2 \mathrm{O} /$ alumina. The data in parentheses were the isolated yields catalyzed by Ag2O/MWCNT.

Afterwards, we examined the feasibility to use the template-supported $\mathrm{Ag}_{2} \mathrm{O}$ in cycle. XPS showed that after the first cycle most of $\mathrm{Ag}_{2} \mathrm{O}$ /diatomite and $\mathrm{Ag}_{2} \mathrm{O} /$ silica were reduced to $\mathrm{Ag}(0)$ 
while only a small part of $\mathrm{Ag}_{2} \mathrm{O} /$ alumina was reduced. The possible reasons for this low reduction of $\mathrm{Ag}_{2} \mathrm{O}$ /alumina are that (1) the faster reaction rate of the $\mathrm{A}^{3}$-coupling catalyzed by $\mathrm{Ag}_{2} \mathrm{O}$ /alumina in comparison with that of the reduction of silver (I) and (2) the smaller $\operatorname{Ag}_{2} \mathrm{O}$ particles supported by alumina were much more active in catalyzing the reaction due to a good immobilization of silver ion on alumina surface. To test our assumption, benzaldehyde, amine, $\mathrm{Ag}_{2} \mathrm{O}$ /alumina and water were stirred at $100^{\circ} \mathrm{C}$. Only after stirring for 10 hours, we observed a completely reduction of silver (I). This indicated that reduction of silver (I) was slower than the $\mathrm{A}^{3}$-coupling reaction. Also, $\mathrm{Ag}_{2} \mathrm{O}$ nanoparticles without templates (10-12 nm) ${ }^{9}$ were prepared. When these nanoparticles were used in the coupling reaction, 77\% isolated yield was achieved in 4 hours and XRD and XPS showed that most part of the silver (I) was reduced to $\operatorname{Ag}(0) . \operatorname{Ag}(0)$ showed no catalytic activity in this $\mathrm{A}^{3}$-coupling reaction. ${ }^{2}$ All of these experimental results indicated that the generation of $\mathrm{Ag}(0)$ resulted in the reduction of the catalytic activity. In Table 3 , we presented the results of recycling the alumina-supported $\mathrm{Ag}_{2} \mathrm{O}$ in a model reaction of benzaldehyde with phenylacetylene and diethylamine. After each cycle, catalyst was recovered by simple centrifugation and washing by water and ethanol twice, and then was reused for the next cycle. The catalyst exhibited $79 \%, 50 \%, 29 \%$ yields in the second, third, fourth cycle, respectively (Table 3, entries 3-5).

Table 3. Observed XPS binding energy peaks for fresh and recycled Ag2O/alumina

\begin{tabular}{|c|c|c|c|c|c|c|}
\hline entry & catalyst $\left(\mathrm{Ag}_{2} \mathrm{O}\right)$ & reaction time $(\mathrm{h})$ & isolated yield & ${\mathrm{Ag} 3 \mathrm{~d}_{5 / 2}}$ & $\mathrm{AgM}_{4} \mathrm{~N}_{45} \mathrm{~N}_{45}$ & Oxidation State \\
\hline 1 & fresh & & & $367.7 \mathrm{eV}$ & 357.4 & $(\phi \tilde{n})$ \\
\hline 2 & the $1^{\text {st }}$ cycle & 2 & $92 \%$ & $368.1 \mathrm{eV}$ & 356.9 & $(\phi \tilde{n})$ \\
\hline 3 & the $2^{\text {nd }}$ cycle & 6 & $79 \%$ & $368.0 \mathrm{eV}$ & $\begin{array}{l}356.7 \\
358.1\end{array}$ & $\begin{array}{c}(\phi \tilde{n}) \\
(0)\end{array}$ \\
\hline 4 & the $3^{\text {rd }}$ cycle & 8 & $50 \%$ & $367.9 \mathrm{eV}$ & $\begin{array}{l}356.9 \\
358.2\end{array}$ & $\begin{array}{c}(\phi \tilde{n}) \\
(0)\end{array}$ \\
\hline 5 & the $4^{\text {th }}$ cycle & 14 & $29 \%$ & $368.2 \mathrm{eV}$ & - & - \\
\hline
\end{tabular}

High resolution XPS Ag narrow scan of the fresh alumina-supported silver oxide showed $\mathrm{Ag} 3 \mathrm{~d}_{5 / 2}$ at $367.7 \mathrm{eV}$ and $\mathrm{AgM}_{4} \mathrm{~N}_{45} \mathrm{~N}_{45}$ at $357.4 \mathrm{eV}$, which are attributed to $\mathrm{Ag}$ (I) oxidation state. $\mathrm{Ag}$ narrow scan in the second (third) cycle showed $\mathrm{Ag} 3 \mathrm{~d}_{5 / 2}$ at 368.0 (367.9) eV and $\mathrm{AgM}_{4} \mathrm{~N}_{45} \mathrm{~N}_{45}$ at 358.1 (358.2) eV, which clearly indicated the formation of Ag (0). We deduced that $\mathrm{Ag}$ (I) was reduced by the aldehyde in the reaction medium. An ideal template should immobilize Ag (I) tightly so that the reaction can be carried out on the surface of the template. Therefore the key point to keep the catalytic activity in the $\mathrm{A}^{3}$-coupling reaction is to find a proper template to encapsulate nano- $\mathrm{Ag}_{2} \mathrm{O}$ tightly and distribute the nanoparticles proportionally.

A succinct mechanism was proposed on the basis of our experimental results together with some literatures. ${ }^{2,3}$ As shown in Scheme 1, the nucleophilic addition of amine to aldehyde generates iminium, and the reaction of alkyne with Ag (I) gives silver acetylide. The silver 
acetylide intermediate then attacks the iminium ion to afford the corresponding propargylamine with the $\mathrm{Ag}$ (I) catalyst being released for further reaction.

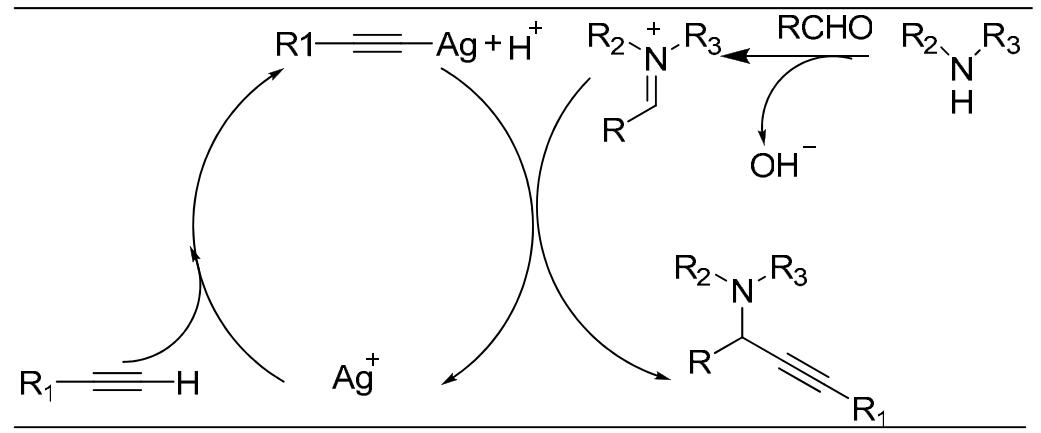

Scheme 1. Plausible mechanism of the $\mathrm{A}^{3}$-coupling reaction

\section{Conclusions}

In conclusion, the nanopaticles of $\mathrm{Ag}_{2} \mathrm{O} /$ alumina and $\mathrm{Ag}_{2} \mathrm{O} / \mathrm{MWCNT}$ were selected as efficient catalysts for the three-component coupling of aldehyde, amine, and alkyne, affording the corresponding propargylamines with high yields and rapid reaction rates. The $\mathrm{Ag}_{2} \mathrm{O} / \mathrm{alumina}$ can be recycled to some extent. The experimental results indicated that the reduction of $\mathrm{Ag}$ (I) is the main reason for the loss of the catalytic activity. This implied that the selection of the template to encapsulate the metal nanoparticles is crucial to keep the catalytic activity, which provides us a clue for exploring the suitable heterogeneous catalyst. Further research is in progress in our laboratory.

\section{Experimental Section}

Typical procedure for the preparation of silica sphere-supported $\mathrm{Ag}_{2} \mathrm{O}$ nanoparticles

To a flask was added $88 \mathrm{~mL}$ of methanol and $12 \mathrm{~mL}$ of $\mathrm{NH}_{3} \cdot \mathrm{H}_{2} \mathrm{O}(25 \%)$, then $3.6 \mathrm{~mL}$ of Si(OEt) 4 was introduced into the flask, stirring for $30 \mathrm{~min}$. The formed silica sphere was filtered and washed by water and methanol for three times. $50 \mathrm{~mL}$ of water and $50 \mathrm{~mL}$ of methanol were mixed. To this mixture the obtained silica sphere was introduced and another $2 \mathrm{mmol}$ of $\mathrm{AgNO}_{3}$ and $15 \mathrm{mmol}$ of $\mathrm{CF}_{3} \mathrm{COOH}$ was added, then stirring for 4 hours. The mixture was centrifuged and the residue was transferred into a flask containing $50 \mathrm{~mL}$ of solvent $\left(V_{\text {water }}: V_{\mathrm{MeOH}}=1: 1\right)$. To this flask $15 \%$ of $\mathrm{n}-\mathrm{Bu}_{4} \mathrm{NOH}$ was added dropwise to adjust the $\mathrm{pH}$ of the solution up to 10 . The silica sphere-supported $\mathrm{Ag}_{2} \mathrm{O}$ was obtained by heating the mixture at $80{ }^{\circ} \mathrm{C}$ for 1 hour.

\section{Typical procedure for the preparation of diatomite-supported $\mathrm{Ag}_{2} \mathrm{O}$ nanoparticles}


$15 \mathrm{~mL}$ of methanol and $15 \mathrm{~mL}$ of water were mixed together. To this mixture diatomite (500 mg), $\mathrm{AgNO}_{3}(2 \mathrm{mmol})$ and $15 \mathrm{mmol}$ of $\mathrm{CF}_{3} \mathrm{COOH}$ were added. After the mixture was stirring for 4 hours, the $\mathrm{pH}$ of the mixture was adjusted to 10 by adding $0.1 \mathrm{M} \mathrm{NaOH}$ dropwise. Then the diatomite-supported $\mathrm{Ag}_{2} \mathrm{O}$ was obtained by heating the mixture at $80{ }^{\circ} \mathrm{C}$ for 1 hour.

\section{Typical procedure for the preparation of MWCNT-supported $\mathrm{Ag}_{2} \mathrm{O}$ nanoparticles}

$150 \mathrm{mg}$ of MWCNT, $5 \mathrm{~mL}$ of $1 \mathrm{M} \mathrm{AgNO} 3,185 \mathrm{~mL}$ of $\mathrm{n}$-hexane and $1.78 \mathrm{~g}$ of bis-(2ethylhexyl)-sodium sulfosuccinate (AOT) (4 mmol), were added into a $250 \mathrm{~mL}$ of flask under vigorous stirring for 6 hours. $15 \mathrm{~mL}$ of $1 \mathrm{M} \mathrm{NaOH}$ aqueous solution was added dropwise into that solution. After stirring for 5 hours, the reaction mixture was diluted with water and then filtered. The solid was dispersed in water and filtered again, and then the filter cake was washed by water for three times. The solid was then washed by acetone and THF for four times to remove the reminder of water and dried under vacuum for 10 hours at $60{ }^{\circ} \mathrm{C}$, giving the desired MWCNT-supported $\mathrm{Ag}_{2} \mathrm{O}$ nanoparticles in good yield.

\section{Typical procedure for $\mathbf{A}^{3}$-coupling reaction}

A mixture of benzaldehyde (212 mg, $2 \mathrm{mmol})$, diethylamine (219 mg, $3 \mathrm{mmol})$, pehnylacetylene (244 mg, $2.4 \mathrm{mmol}$ ) and $\mathrm{Ag}_{2} \mathrm{O} /$ alumina catalyst $(50 \mathrm{mg})$ in $\mathrm{H}_{2} \mathrm{O}(2 \mathrm{~mL})$ was stirred at $100{ }^{\circ} \mathrm{C}$. After completion of the reaction (monitored by TLC), the catalyst was filtered. The product was transferred to the aqueous phase by addition of $10 \mathrm{~mL}$ of $2 \mathrm{M} \mathrm{HCl}$ and the aqueous phase was washed by EtOAc $(3 \times 10 \mathrm{~mL})$. Then the aqueous phase was neutralized and the product was extracted by EtOAc $(3 \times 5 \mathrm{~mL})$. Completing evaporation of the organic solvent gave the desired crude product which was purified by column chromatography over silica gel to give high purity product. The filtered catalyst was washed by $\mathrm{MeOH}(3 \times 5 \mathrm{~mL})$ and dried at $50^{\circ} \mathrm{C}$ for 1 hour then was added in the coupling reaction for next cycle.

$\boldsymbol{N}, \boldsymbol{N}$-Diethyl-1,3-diphenylprop-2-yn-1-amine (1). ${ }^{1} \mathrm{H} \mathrm{NMR}\left(\mathrm{CDCl}_{3}, 300 \mathrm{MHz}, \mathrm{ppm}\right): \delta=7.70$ 7.67 (m, 2 H), 7.51-7.49 (m, 2 H), 7.34-7.30 (m, 6 H), 5.05 (s, 1 H), 2.68-2.52 (m, 4 H), 1.08 (t, J $=7.1 \mathrm{~Hz}, 6 \mathrm{H}) .{ }^{13} \mathrm{C} \mathrm{NMR}\left(\mathrm{CDCl}_{3}, 75 \mathrm{MHz}, \mathrm{ppm}\right): \delta=140.0,131.9,128.5,128.4,128.2$ (two signals overlap), 127.4, 123.6, 87.6, 86.3, 57.2, 44.7, 13.7. IR (Liquid film, $\mathrm{cm}^{-1}$ ): $v=3061$, 2969, 2932, 2821, 1599, 1490, 1449, 1050, 756, 692. HRMS Calcd. $\mathrm{C}_{19} \mathrm{H}_{21} \mathrm{~N}\left(\mathrm{M}^{+}\right)$: 263.1674. Found: 263.1680.

1-(4-Chlorophenyl)- $\mathbf{N}, \boldsymbol{N}$-diethyl-3-phenylprop-2-yn-1-amine (2). ${ }^{1} \mathrm{H} \mathrm{NMR}\left(\mathrm{CDCl}_{3}, 300 \mathrm{MHz}\right.$, ppm): $\delta=7.64-7.61(\mathrm{~m}, 2 \mathrm{H}), 7.51-7.48(\mathrm{~m}, 2 \mathrm{H}), 7.34-7.30(\mathrm{~m}, 5 \mathrm{H}), 4.99(\mathrm{~s}, 1 \mathrm{H}), 2.67-2.47$ $(\mathrm{m}, 4 \mathrm{H}), 1.07(\mathrm{t}, \mathrm{J}=4.0 \mathrm{~Hz}, 6 \mathrm{H}) .{ }^{13} \mathrm{C} \mathrm{NMR}\left(\mathrm{CDCl}_{3}, 75 \mathrm{MHz}, \mathrm{ppm}\right): \delta=139.1,133.4,132.3$, 130.1, 128.8, 128.6 (two signals overlap), 123.6, 88.3, 86.0, 57.0, 45.1, 14.1. IR (Liquid film, $\left.\mathrm{cm}^{-1}\right): v=3057,2969,2932,2822,1597,1488,1470,1383,1287,1091,1016,755,690$. HRMS Calcd. $\mathrm{C}_{19} \mathrm{H}_{20}{ }^{35} \mathrm{ClN}\left(\mathrm{M}^{+}\right)$: 297.1284. Found: 297.1289 .

$\boldsymbol{N}, \boldsymbol{N}$-Diethyl-3-phenyl-1-p-tolylprop-2-yn-1-amine (3). ${ }^{1} \mathrm{H} \mathrm{NMR}\left(\mathrm{CDCl}_{3}, 300 \mathrm{MHz}, \mathrm{ppm}\right): \delta=$ 7.62-7.52 (m, $4 \mathrm{H}), 7.35-7.33(\mathrm{~m}, 3 \mathrm{H}), 7.20-7.18(\mathrm{~m}, 2 \mathrm{H}), 5.06(\mathrm{~s}, 1 \mathrm{H}), 2.75-2.53(\mathrm{~m}, 4 \mathrm{H})$, $2.38(\mathrm{~s}, 3 \mathrm{H}), 1.12(\mathrm{t}, \mathrm{J}=7.1 \mathrm{~Hz}, 6 \mathrm{H}) .{ }^{13} \mathrm{C} \mathrm{NMR}\left(\mathrm{CDCl}_{3}, 75 \mathrm{MHz}, \mathrm{ppm}\right): \delta=136.9,136.8$, 
131.8, 128.8, 128.3 (two signals overlap), 128.0, 123.6, 87.4, 86.5, 56.9, 44.6, 21.1, 13.7. IR $\left(\mathrm{KBr}\right.$ pellet, $\left.\mathrm{cm}^{-1}\right): v=3054,2969,2820,1598,1509,1490,1051,756,691$. HRMS Calcd. $\mathrm{C}_{20} \mathrm{H}_{23} \mathrm{~N}\left(\mathrm{M}^{+}\right): 277.1830$. Found: 277.1836.

$\boldsymbol{N}, \boldsymbol{N}$-Diethyl-1-(4-methoxyphenyl)-3-phenylprop-2-yn-1-amine (4). ${ }^{1} \mathrm{H} \mathrm{NMR}\left(\mathrm{CDCl}_{3}, 300\right.$ MHz, ppm): $\delta=7.60-7.57$ (m, $2 \mathrm{H}), 7.51-7.48$ (m, $2 \mathrm{H}), 7.32-7.30$ (m, $3 \mathrm{H}), 6.90-6.87$ (m, $2 \mathrm{H})$, $4.99(\mathrm{~s}, 1 \mathrm{H}), 3.80(\mathrm{~s}, 3 \mathrm{H}), 2.67-2.50(\mathrm{~m}, 4 \mathrm{H}), 1.07(\mathrm{t}, \mathrm{J}=7.1 \mathrm{~Hz}, 6 \mathrm{H}) .{ }^{13} \mathrm{C} \mathrm{NMR}\left(\mathrm{CDCl}_{3}, 75\right.$ $\mathrm{MHz}, \mathrm{ppm}): \delta=158.9,132.0,131.8,129.5,128.3,128.0,123.6,113.5,87.4,86.6,56.6,55.2$, 44.5, 13.7. IR (KBr pellet, $\left.\mathrm{cm}^{-1}\right): v=2968,2834,1610,1509,1490,1464,1247,1171,1038$, 833, 756, 691. HRMS Calcd. $\mathrm{C}_{20} \mathrm{H}_{23} \mathrm{NO}\left(\mathrm{M}^{+}\right)$: 293.1780. Found: 293.1786.

1-(Benzo $[\boldsymbol{d}][\mathbf{1}, 3]$ dioxol-6-yl)- $\boldsymbol{N}, \boldsymbol{N}$-diethyl-3-phenylprop-2-yn-1-amine (5). ${ }^{1} \mathrm{H} \mathrm{NMR}\left(\mathrm{CDCl}_{3}\right.$, $300 \mathrm{MHz}, \mathrm{ppm}): \delta=7.50-7.46(\mathrm{~m}, 2 \mathrm{H}), 7.32-7.30(\mathrm{~m}, 3 \mathrm{H}), 7.19-7.18(\mathrm{~m}, 2 \mathrm{H}), 6.78(\mathrm{~d}, \mathrm{~J}=8.6$ $\mathrm{Hz}, 1 \mathrm{H}), 5.95$ (s, $2 \mathrm{H}), 4.94(\mathrm{~s}, 1 \mathrm{H}), 2.69-2.47(\mathrm{~m}, 4 \mathrm{H}), 1.07$ (t, J= 7.1 Hz, $6 \mathrm{H}) .{ }^{13} \mathrm{C}$ NMR $\left(\mathrm{CDCl}_{3}, 75 \mathrm{MHz}, \mathrm{ppm}\right): \delta=147.7,146.9,134.1,131.9,128.4,128.2,123.5,121.7,109.0,107.8$, 101.1, 87.6, 86.4, 57.0, 44.6, 13.7. IR ( $\mathrm{KBr}$ pellet, $\left.\mathrm{cm}^{-1}\right): v=2969,2931,1598,1503,1487$, 1439, 1234, 1041, 938, 756, 691. HRMS Calcd. $\mathrm{C}_{20} \mathrm{H}_{21} \mathrm{NO}_{2}\left(\mathrm{M}^{+}\right)$: 307.1572. Found: 307.1580.

$\boldsymbol{N}, \boldsymbol{N}$-Diethyl-3-phenylprop-2-yn-1-amine (6). ${ }^{1} \mathrm{H} \mathrm{NMR}\left(\mathrm{CDCl}_{3}, 300 \mathrm{MHz}, \mathrm{ppm}\right): \delta=7.44-7.40$ (m, $2 \mathrm{H}), 7.30-7.26(\mathrm{~m}, 3 \mathrm{H}), 3.64(\mathrm{~s}, 2 \mathrm{H}), 2.63$ (q, J= 7.1 Hz, $4 \mathrm{H}), 1.12$ (t, J = 7.1 Hz, $6 \mathrm{H}) .{ }^{13} \mathrm{C}$ NMR $\left(\mathrm{CDCl}_{3}, 75 \mathrm{MHz}, \mathrm{ppm}\right): \delta=131.7,128.2,127.9,123.8,85.0,84.5,47.3,41.5,12.7$. IR $\left(\mathrm{KBr}\right.$ pellet, $\left.\mathrm{cm}^{-1}\right): v=3058,2971,2934,2819,2185,1598,1489,1460,1381,1321,1066,691$. HRMS Calcd. $\mathrm{C}_{13} \mathrm{H}_{17} \mathrm{~N}\left(\mathrm{M}^{+}\right)$: 187.1361. Found: 187.1366 .

$\boldsymbol{N}, \boldsymbol{N}$-Diethyl-1-phenylnon-1-yn-3-amine (7). ${ }^{1} \mathrm{H} \mathrm{NMR}\left(\mathrm{CDCl}_{3}, 300 \mathrm{MHz}, \mathrm{ppm}\right): \delta=7.43-7.40$ $(\mathrm{m}, 2 \mathrm{H}), 7.30-7.27(\mathrm{~m}, 3 \mathrm{H}), 3.68(\mathrm{t}, \mathrm{J}=6.8 \mathrm{~Hz}, 1 \mathrm{H}), 2.76-2.69(\mathrm{~m}, 2 \mathrm{H}), 2.53-2.46$ (m, $2 \mathrm{H})$, 1.73-1.69 (m, 2 H), 1.69 (br, 2 H), 1.52 (br, 6 H), 1.10 (t, J=7.2 Hz, 6 H), 0.90 (t, J=6.5 Hz, 3 H). ${ }^{13} \mathrm{C} \mathrm{NMR}\left(\mathrm{CDCl}_{3}, 75 \mathrm{MHz}, \mathrm{ppm}\right): \delta=131.8,128.3,127.8,123.9,89.3,84.7,53.9,45.0$, 34.4, 31.9, 29.2, 26.9, 22.8, 14.2, 13.9. IR (KBr pellet, $\left.\mathrm{cm}^{-1}\right): v=3057,2929,2856,1598,1489$, 1467, 1380, 1197, 1068, 755, 691. HRMS Calcd. $\mathrm{C}_{19} \mathrm{H}_{29} \mathrm{~N}\left(\mathrm{M}^{+}\right): 271.2300$. Found: 271.2304.

$\boldsymbol{N}, \boldsymbol{N}$-Diethyl-3-phenyl-1-(pyridin-3-yl) prop-2-yn-1-amine (8). ${ }^{1} \mathrm{H} \mathrm{NMR}\left(\mathrm{CDCl}_{3}, 300 \mathrm{MHz}\right.$, ppm): $\delta=8.92(\mathrm{dd}, \mathrm{J}=0.8,1.4 \mathrm{~Hz}, 1 \mathrm{H}), 8.53(\mathrm{dd}, \mathrm{J}=1.2,4.7 \mathrm{~Hz}, 1 \mathrm{H}), 8.00-7.95(\mathrm{~m}, 1 \mathrm{H}), 7.52-$ $7.49(\mathrm{~m}, 2 \mathrm{H}), 7.34-7.32(\mathrm{~m}, 3 \mathrm{H}), 7.30-7.26(\mathrm{~m}, 1 \mathrm{H}), 5.06(\mathrm{~s}, 1 \mathrm{H}), 2.69-2.52(\mathrm{~m}, 4 \mathrm{H}), 1.08(\mathrm{t}$, $\mathrm{J}=7.1 \mathrm{~Hz}, 6 \mathrm{H}) .{ }^{13} \mathrm{C} \mathrm{NMR}\left(\mathrm{CDCl}_{3}, 75 \mathrm{MHz}, \mathrm{ppm}\right): \delta=150.1,148.6,135.8,135.5,131.8,128.3$, 128.2, 123.0, 122.90, 88.2, 84.6, 55.1, 44.6, 13.6. IR (KBr pellet, $\left.\mathrm{cm}^{-1}\right): v=3413,2970,2218$, 1671, 1576, 1474, 1287, 1054, 756, 692. HRMS Calcd. $\mathrm{C}_{18} \mathrm{H}_{20} \mathrm{~N}_{2}\left(\mathrm{M}^{+}\right)$: 264.1626. Found: 264.1631.

$\boldsymbol{N}, \boldsymbol{N}$-Diethyl-1-phenylhex-2-yn-1-amine (9). ${ }^{1} \mathrm{H} \mathrm{NMR}\left(\mathrm{CDCl}_{3}, 300 \mathrm{MHz}, \mathrm{ppm}\right): \delta=7.63-7.59$ (m, 2 H), 7.34-7.32 (m, 2 H), 7.26-7.22 (m, $1 \mathrm{H}), 4.80$ (s, $1 \mathrm{H})$, 2.55-2.40 (m, $4 \mathrm{H}), 2.31-2.26$ (m, $2 \mathrm{H}), 1.63-1.56(\mathrm{~m}, 2 \mathrm{H}), 1.06-1.00(\mathrm{~m}, 9 \mathrm{H}) .{ }^{13} \mathrm{C} \mathrm{NMR}\left(\mathrm{CDCl}_{3}, 75 \mathrm{MHz}, \mathrm{ppm}\right): \delta=140.7$, 128.5, 128.0, 127.1, 87.4, 76.3, 56.7, 44.6, 22.7, 21.0, 13.7 (two signals overlap). IR (KBr pellet, $\left.\mathrm{cm}^{-1}\right): v=3061,2966,2821,2257,1601,1491,1451,1381,1196,724,697$. HRMS Calcd. $\mathrm{C}_{16} \mathrm{H}_{23} \mathrm{~N}\left(\mathrm{M}^{+}\right)$: 229.1830. Found: 229.1822 . 
$\boldsymbol{N}, \boldsymbol{N}$-Diethylhex-2-yn-1-amine (10). ${ }^{1} \mathrm{H} \mathrm{NMR}\left(\mathrm{CDCl}_{3}, 300 \mathrm{MHz}, \mathrm{ppm}\right): \delta=3.39-3.38(\mathrm{~m}, 2 \mathrm{H})$, 2.54 (q, J = 7.2 Hz, 4 H), 2.20-2.14 (m, 2 H), 1.56-1.49 (m, 2 H), 1.06 (t, J = 7.2 Hz, 6 H), 0.98 $(\mathrm{t}, \mathrm{J}=7.3 \mathrm{~Hz}, 3 \mathrm{H}) .{ }^{13} \mathrm{C} \mathrm{NMR}\left(\mathrm{CDCl}_{3}, 75 \mathrm{MHz}, \mathrm{ppm}\right): \delta=84.7,74.4,47.1,40.9,22.4,20.7$, 13.4, 12.5. IR (KBr pellet, $\left.\mathrm{cm}^{-1}\right): v=2970,2819,2260,1461,1379,1322,1202,1091,981,764$. HRMS Calcd. $\mathrm{C}_{10} \mathrm{H}_{19} \mathrm{~N}\left(\mathrm{M}^{+}\right)$: 153.1517. Found: 153.1509 .

1-(3-Phenylprop-2-ynyl)piperidine (11). ${ }^{1} \mathrm{H}$ NMR $\left(\mathrm{CDCl}_{3}, 300 \mathrm{MHz}, \mathrm{ppm}\right): \delta=7.45-7.41$ (m, $2 \mathrm{H}), 7.30-7.27$ (m, $3 \mathrm{H}), 3.47$ (s, $2 \mathrm{H}), 2.57$ (br, $4 \mathrm{H}), 1.68-1.61(\mathrm{~m}, 4 \mathrm{H}), 1.45$ (br, $2 \mathrm{H}) .{ }^{13} \mathrm{C}$ NMR $\left(\mathrm{CDCl}_{3}, 75 \mathrm{MHz}, \mathrm{ppm}\right): \delta=131.5,127.9,127.7,123.2,84.9,84.8,53.2,52.8,48.3,25.8$, 23.8. IR (KBr pellet, $\mathrm{cm}^{-1}$ ): $v=3056,2934,1876,1599,1489,1442,1155,1108,860,755,691$. HRMS Calcd. $\mathrm{C}_{14} \mathrm{H}_{17} \mathrm{~N}\left(\mathrm{M}^{+}\right)$: 199.1361. Found: 199.1352.

1-(4-Methyl-1-phenylpent-1-yn-3-yl)piperidine (12). ${ }^{1} \mathrm{H} \mathrm{NMR}\left(\mathrm{CDCl}_{3}, 300 \mathrm{MHz}, \mathrm{ppm}\right): \delta=$ 7.44-7.41 (m, 2 H), 7.27-7.25 (m, 3 H), 2.98 (d, J = 9.6 Hz, 1 H), 2.65-2.59 (m, 2 H), 2.44-2.37 $(\mathrm{m}, 2 \mathrm{H}), 1.93-1.81(\mathrm{~m}, 1 \mathrm{H}), 1.61-1.58(\mathrm{~m}, 4 \mathrm{H}), 1.44-1.41(\mathrm{~m}, 2 \mathrm{H}), 1.09(\mathrm{~d}, \mathrm{~J}=6.6 \mathrm{~Hz}, 3 \mathrm{H})$, $1.0(\mathrm{~d}, \mathrm{~J}=6.6 \mathrm{~Hz}, 3 \mathrm{H}) .{ }^{13} \mathrm{C} \mathrm{NMR}\left(\mathrm{CDCl}_{3}, 75 \mathrm{MHz}, \mathrm{ppm}\right): \delta=131.8,128.3,127.7,123.9,87.9$, 86.2, 65.8, 50.9, 30.6, 26.4, 24.9, 20.8, 20.0. IR (KBr pellet, $\left.\mathrm{cm}^{-1}\right): v=2933,2804,1598,1489$, 1443, 1323, 1261, 1096, 1005, 755, 690. HRMS Calcd. $\mathrm{C}_{17} \mathrm{H}_{23} \mathrm{~N}\left(\mathrm{M}^{+}\right)$: 241.183. Found: 241.1822 .

1-(5-Methyl-1-phenylhex-1-yn-3-yl)piperidine (13). ${ }^{1} \mathrm{H} \mathrm{NMR}\left(\mathrm{CDCl}_{3}, 300 \mathrm{MHz}, \mathrm{ppm}\right): \delta=$ 7.45-7.41 (m, 2 H), 7.30-7.26 (m, 3 H), 3.61-3.56 (dd, J = 5.8, 9.4 Hz, 1 H), 2.73-2.67 (m, 2 H), 2.52-2.50 (m, $2 \mathrm{H}), 1.89-1.87(\mathrm{~m}, 1 \mathrm{H}), 1.70-1.56(\mathrm{~m}, 6 \mathrm{H}), 1.49-1.44(\mathrm{~m}, 2 \mathrm{H}), 0.97$ (d, J = 6.9 $\mathrm{Hz}, 3 \mathrm{H}), 0.95(\mathrm{~d}, \mathrm{~J}=6.8 \mathrm{~Hz}, 3 \mathrm{H}) .{ }^{13} \mathrm{C} \mathrm{NMR}\left(\mathrm{CDCl}_{3}, 75 \mathrm{MHz}, \mathrm{ppm}\right): \delta=131.8,128.3,127.8$, 123.7, 88.2, 85.8, 56.8, 50.7, 42.4, 26.3, 25.5, 24.7, 23.2, 22.2. IR (KBr pellet, $\left.\mathrm{cm}^{-1}\right): v=3056$, 2933, 2804, 2750, 1598, 1573, 1489, 1467, 1158, 1097, 987, 755, 691. HRMS Calcd. $\mathrm{C}_{18} \mathrm{H}_{25} \mathrm{~N}$ $\left(\mathrm{M}^{+}\right)$: 255.1987. Found: 255.1996.

1-(1-Phenylhex-1-yn-3-yl)piperidine (14). ${ }^{1} \mathrm{H}$ NMR $\left(\mathrm{CDCl}_{3}, 300 \mathrm{MHz}, \mathrm{ppm}\right): \delta=7.45-7.42$ (m, $2 \mathrm{H}), 7.30-7.27$ (m, $3 \mathrm{H}), 3.52-3.47$ (dd, J = 5.4, 8.7 Hz, $1 \mathrm{H}), 2.72-2.65$ (m, $2 \mathrm{H}), 2.52-2.47$ $(\mathrm{m}, 2 \mathrm{H}), 1.73-1.63(\mathrm{~m}, 7 \mathrm{H}), 1.49-1.43(\mathrm{~m}, 3 \mathrm{H}), 0.97(\mathrm{t}, \mathrm{J}=7.5 \mathrm{~Hz}, 3 \mathrm{H}) .{ }^{13} \mathrm{C} \mathrm{NMR}\left(\mathrm{CDC}_{13}, 75\right.$ MHz, ppm): $\delta=131.8,128.3,127.8,123.7,88.3,85.7,58.4,50.7,35.7,26.3,24.7,20.2,14.0$. IR $\left(\mathrm{KBr}\right.$ pellet, $\left.\mathrm{cm}^{-1}\right): v=3056,2931,2750,1598,1489,1325,1273,1158,1117,979,911,755$, 691. HRMS Calcd. $\mathrm{C}_{17} \mathrm{H}_{23} \mathrm{~N}\left(\mathrm{M}^{+}\right)$: 241.183 Found: 241.1835.

1-(3-Phenylprop-2-ynyl)pyrrolidine (15). ${ }^{1} \mathrm{H}$ NMR $\left(\mathrm{CDCl}_{3}, 300 \mathrm{MHz}, \mathrm{ppm}\right): \delta=7.42-7.41$ (m, $2 \mathrm{H})$, 7.30-7.26 (m, $3 \mathrm{H}), 3.63(\mathrm{~s}, 2 \mathrm{H}), 2.71-2.70(\mathrm{~m}, 4 \mathrm{H}), 1.86-1.83(\mathrm{~m}, 4 \mathrm{H}) .{ }^{13} \mathrm{C} \mathrm{NMR}$ $\left(\mathrm{CDCl}_{3}, 75 \mathrm{MHz}, \mathrm{ppm}\right): \delta=131.5,128.0,127.7,123.1,85.2,84.2,52.5,43.6,23.6$. IR $(\mathrm{KBr}$ pellet, $\left.\mathrm{cm}^{-1}\right): v=2966,2793,1649,1598,1489,1322,1124,756,691$. HRMS Calcd. $\mathrm{C}_{13} \mathrm{H}_{15} \mathrm{~N}$ $\left(\mathrm{M}^{+}\right):$185.1204. Found: 185.1199.

1-(1-(4-Methoxyphenyl)-3-phenylprop-2-ynyl)pyrrolidine (16). ${ }^{1} \mathrm{H} \mathrm{NMR}\left(\mathrm{CDCl}_{3}, 300 \mathrm{MHz}\right.$, ppm): $\delta=7.53-7.47(\mathrm{~m}, 4 \mathrm{H}), 7.32-7.30(\mathrm{~m}, 3 \mathrm{H}), 6.91-6.88(\mathrm{~m}, 2 \mathrm{H}), 4.83(\mathrm{~s}, 1 \mathrm{H}), 3.81(\mathrm{~s}, 3 \mathrm{H})$, 2.68 (br, $4 \mathrm{H}$ ), 1.80 (br, $4 \mathrm{H}) .{ }^{13} \mathrm{C} \mathrm{NMR}\left(\mathrm{CDCl}_{3}, 75 \mathrm{MHz}, \mathrm{ppm}\right): \delta=159.2,131.9$ (two signals overlap), 129.5, 128.3, 128.1, 123.4, 113.7, 87.2, 86.8, 58.6, 55.4, 50.3, 23.6. IR (KBr pellet, $\mathrm{cm}^{-}$ 
$\left.{ }^{1}\right): v=2963,2806,1609,1509,1461,1248,1171,1036,833,756,691$. HRMS Calcd. $\mathrm{C}_{20} \mathrm{H}_{21} \mathrm{NO}$ $\left(\mathrm{M}^{+}\right)$: 291.1623. Found: 291.1629.

1-(4-Methyl-1-phenylpent-1-yn-3-yl)pyrrolidine (17). ${ }^{1} \mathrm{H}$ NMR $\left(\mathrm{CDCl}_{3}, 300 \mathrm{MHz}, \mathrm{ppm}\right): \delta=$ 7.43-7.41 (m, $2 \mathrm{H}), 7.32-7.26$ (m, $3 \mathrm{H}), 3.27$ (d, J = 7.8 Hz, $1 \mathrm{H}), 2.76-2.68$ (m, $4 \mathrm{H}), 1.95-1.88$ $(\mathrm{m}, 1 \mathrm{H}), 1.80(\mathrm{br}, 4 \mathrm{H}), 1.13(\mathrm{~d}, \mathrm{~J}=6.6 \mathrm{~Hz}, 3 \mathrm{H}), 1.06(\mathrm{~d}, \mathrm{~J}=6.6 \mathrm{~Hz}, 3 \mathrm{H}) .{ }^{13} \mathrm{C} \mathrm{NMR}\left(\mathrm{CDCl}_{3}\right.$, $75 \mathrm{MHz}, \mathrm{ppm}): \delta=131.8,128.2,127.8,123.7,87.7,85.8,62.6,50.4,32.0,23.6,20.3,19.5$. HRMS Calcd. $\mathrm{C}_{16} \mathrm{H}_{21} \mathrm{~N}\left(\mathrm{M}^{+}\right)$: 227.1674. Found: 227.1669.

4-(3-Phenyl-prop-2-ynyl)-morpholine (18). ${ }^{1} \mathrm{H}$ NMR $\left(\mathrm{CDCl}_{3}, 300 \mathrm{MHz}, \mathrm{ppm}\right): \delta=7.45-7.43$ $(\mathrm{m}, 2 \mathrm{H}), 7.31-7.29(\mathrm{~m}, 3 \mathrm{H}), 3.77(\mathrm{t}, \mathrm{J}=4.5,4 \mathrm{H}), 3.51(\mathrm{~s}, 2 \mathrm{H}), 2.64(\mathrm{t}, \mathrm{J}=4.5 \mathrm{~Hz}, 4 \mathrm{H}) .{ }^{13} \mathrm{C}$ NMR (CDCl $375 \mathrm{MHz}, \mathrm{ppm}): \delta=131.6,128.1,128.0,122.9,85.4,84.0,66.7,52.3,47.9$. IR $\left(\mathrm{KBr}\right.$ pellet, $\left.\mathrm{cm}^{-1}\right): v=2959,2854,2814,1598,1489,1331,1116,1006,862,757,692 . \mathrm{HRMS}$ Calcd. $\mathrm{C}_{13} \mathrm{H}_{15} \mathrm{NO}\left(\mathrm{M}^{+}\right)$: 201.1154. Found: 201.1159.

\section{Acknowledgements}

The authors are grateful to National Natural Science Foundation of China (No. 30572234) for their support.

\section{References and Notes}

1. (a) Mark, A. F.; Nobuyoshi, Y.; Ann, E. D.; Edward, J. J. G. J. Org. Chem. 1995, 60, 1590. (b) Masataka, K.; Hiroaki, O.; Takashi, T.; Toshikazu, O.; Gregory, D. V.; Jon, C. J. Am. Chem. Soc. 1990, 112, 3715. (c) Naota, I.; Takaya, H.; Murahashi, S. I. Chem. Rev. 1998, 98, 2599. (d) Dyker, G. Angew. Chem Int. Ed. 1999, 38, 1698. (e) Nilsson, B.; Vargas, H. M.; Ringdahl, B.; Hacksell, U. J. Med. Chem. 1992, 35, 285. (f) Hattori, K.; Miyata, M.; Yamamoto, H. J. Am. Chem. Soc. 1993, 115, 1151. (g) Jenmalm, A.; Berts, W.; Li, Y. L.; Luthman, K.; Csoregh, I.; Hacksell, U. J. Org. Chem. 1994, 59, 1139. (h) Miura, M.; Enna, M.; Okuro, K.; Nomura, M. J. Org. Chem. 1995, 60, 4999.

2. (a) Miura, M.; Enna, M.; Okura, K.; Nomura, M. J. Org. Chem. 1995, 60, 4999. (b) Fisher, C.; Carreira, E. M. Org. Lett. 2001, 3, 4319. (c) Fallser, R.; Frantz, D. E.; Oetiker, J.; Carreira, E. M. Angew. Chem. Int. Ed. 2002, 41, 3054. (d) Li, C.-J.; Wei, C. M. Chem. Commun. 2002, 268. (e) Wei, C. M.; Li, C.-J. J. Am. Chem. Soc. 2003, 124, 5638. (f) Wei, C. M.; Li, C.-J. J. Am. Chem. Soc. 2002, 125, 9584.

3. (a) Wei, C.; Li, Z.; Li, C.-J. Org. Lett. 2003, 5, 4473. (b) Li, Z.; Wei, C.; Chen, L.; Varma, R. S.; Li, C.-J. Tetrahedron Lett. 2004, 45, 2443. (c) Yao, X.; Li, C.-J. Org. Lett. 2005, 7, 4395.

4. (a) Astruc, D.; Lu, F.; Jaime, R. A. Angew. Chem. Int. Ed. Engl. 2005, 44, 7852. (b) Yoon, B.; Wai, C. B. J. Am. Chem. Soc. 2005, 127, 17174. (c) Yeung, C. M. Y.; Yu, K. M. K.; Fu, Q. J.; Thompsett, D.; Petch, M. I.; Tsang, S. C. J. Am. Chem. Soc. 2005, 127, 18010. (d) Ferreira, 
P.; Phillips, E.; Rippon, D.; Tsang, S. C.; Hayes, W. J. Org. Chem. 2004, 69, 6851. (e) Sau, T. K.; Pal, A.; Pal, T. J. Phys. Chem. B 2001, 105, 9266. (f) Zheng, N.; Skucky, G. D. J. Am. Chem. Soc. 2006, 128, 14278. (g) Grigg, R.; Kilner, C.; Senthilnanthanan, M.; Seabourne, C. R.; Sridharan, V.; Murrer, B. A. ARKIVOC 2007, (xi), 145.

5. (a) Vos, D. E.; Vankelecom, I. F. K.; Jacobs, P. A. Chiral Catalyst Immobilization and Recycling: Wiley-VCH: Weinhein. 2000. (b) Inaki, Y.; Kajita, Y.; Hisao, H.; Yoshida, K.; Ho, K.; Hattori, T. Chem. Commun. 2001, 2358. (c) Arhancet, J. P.; Davis, M. E.; Merola, J. S.; Hanson, B. E. Nature 1989, 339, 454. (d) Oila, M. J.; Koskinen, A. M. P. ARKIVOC 2006, (xv), 76.

6. (a) Posner, G. H. Angew. Chem. Int. Ed. 1978, 17, 487. (b) McKillop, A.; Young, D. W. Synthesis 1979, 401; 408. (c) Cornelis, A.; Laszlo, P. In Chemical Reaction in Organic and Inorganic Constrained System; Setton, R. Ed.; Reider: Dordrecht, 1986; pp 212. (d) Firouzabadi, H.; Iranpoor, N.; Sobhani, S. Tetrahedron Lett. 2002, 43, 477. (e) Sharghi, H.; Niknam, K.; Massah, A. R. J. Heterocyl. Chem. 1999, 36, 601. (f) Shockravi, A.; Sharghi, H.; Valizadeh, H.; Heravi, M. M. Phosphorus, Sulfur Silicon 2002, 177, 2555. (g) Kazemi, F.; Sharghi, H.; Nasseri, M. A. Synthesis 2004, 2, 205. (h) Zhou, Z. W.; Zhao, Y. C.; Yue, Y.; Wu, J.; Yang, M.; Yu, X. Q. ARKIVOC 2005, (i), 130. (i) Palacios, F.; de los Santos, J.; Aparicio, D. ARKIVOC 2005, (ix), 405. (j) Romanelli, G. P.; Ruiz, D. M.; Bidegerripe, H. P.; Autino, J. C.; Baronetti, G. T.; Thomas, H. J. ARKIVOC 2007, (i), 1.

7. (a) Berkovich, Y.; Garti, N. Colloids Surf., A 1997, 129, 91. (b) Grunwaldt, J. D.; Kiener, C.; Wogerbauer, C.; Baiker, A. J. Catal. 1999, 181, 223. (c) Tsybulya, S. V.; Kryukova, G. N.; Gonchavova, S. N.; Shmakov, A. N.; Balzhiunimaev, B. S. J. Catal. 1995, 154, 194. (d) Mastikhin, V. M.; Goncharova, S. N.; Tapilin, V. M.; Terskikh, V. V.; Batzhiunimaev, B. S. J. Mol. Catal. A: Chemika 1995, 96, 175. (e) Carnes, C. L.; Klabunde, K. J. Langmiur 2000, 16, 3764. (f) Stask, J. V.; Park, D. G.; Lagadic, I.; Klabunde, K. J. Chem. Mater. 1996, 8, 1904. (g) Rao, C. N. R.; Vijayakrishman, V.; Santra, A. K.; Prins, M. W. J. Angew. Chem. Int. Ed. Engl. 1992, 1, 1062.

8. (a) Choudary, B. M.; Sridhar, C.; Kantam, M. L.; Sreedhar, B. Tetrahedron Lett. 2004, 45, 7319. (b) Kantam, M. L.; Prakash, B. V.; Reddy, C. R. V.; Sreedhar, B. Synlett 2005, 2329.

9. $\mathrm{Ag}_{2} \mathrm{O}$ nanoparticles were synthesized as follows: $0.01 \mathrm{M} \mathrm{NaOH}$ was added to $20 \mathrm{~mL}$ of 0.01 $\mathrm{M} \mathrm{AgNO}_{3}$ solution dropwise till the $\mathrm{pH}$ up to 10 . The mixture was centrifuged and washed by water for several times. Then the silver(I) oxide powder was dried at $100{ }^{\circ} \mathrm{C}$ for 4 hours. TEM image showed that the particle size was mainly distributed in the range of $10-12 \mathrm{~nm}$. 